\title{
Analysis of the peasants' livelihood strategies in the Paute basin of Ecuador
}

\section{Análisis de las estrategias de sustento de los campesinos en la cuenca del Paute de Ecuador}

\author{
Raúl Vanegas $^{\text {ID }}$, Fabrice Demoulin ${ }^{2}$, Guido Ruivenkamp ${ }^{3}$ and Sabine Henry 4 (D) \\ ${ }^{1}$ Professor and researcher, Faculty of Agricultural Sciences, University of Cuenca, Ecuador. \\ ${ }^{2}$ Former researcher, Department of Geography, University of Namur, Belgium. \\ ${ }^{3}$ Emeritus associate professor, University of Wageningen. Extraordinary professor, University of Utrecht, The Netherlands. \\ ${ }^{4}$ Professor and researcher, Department of Geography and member of the ILEE Research Institute, University of Namur, \\ Belgium.
}

Autor de correspondencia: raul.vanegas@ucuenca.edu.ec

Fecha de recepción: 12 de noviembre de 2020 - Fecha de aceptación: 11 de diciembre de 2020

\begin{abstract}
The article analyses the livelihood of peasant farmers in the rural area of three parishes in the Paute basin in Ecuador. First, the article presents the gathered empirical data of the study sites, respectively the Pichacay in the Santa Ana parish, Caldera in the Javier Loyola parish, and Llavircay in the Rivera parish. Applying the Chayanovian and van der Ploeg interpretation frames, three types of peasant households could be distinguished, based upon their specific organizational forms of producing and reproducing their livelihoods. The article concludes that a more in-depth analysis is needed in the peasant's art of farming, particularly in their core balance of being conditioned by and linked to as well as resistant to the capitalist economy.
\end{abstract}

Keywords: Farming, peasantry, livelihoods, household, typology, Andes.

\section{RESUMEN}

El artículo analiza la forma de sustento de los campesinos en el área rural de tres parroquias de la cuenca del Paute en Ecuador. En primer lugar, el artículo presenta los datos empíricos recopilados de los sitios de estudio, respectivamente Pichacay en la parroquia Santa Ana, Caldera en la parroquia Javier Loyola y Llavircay en la parroquia Rivera. Aplicando el marco de interpretación de Chayanov y van der Ploeg, se podrían distinguir tres tipos de hogares campesinos, basados en sus formas organizativas específicas de producir y reproducir sus medios de vida. El artículo concluye que es necesario un análisis más profundo del arte campesino de la agricultura, particularmente en su balance central de estar condicionado y vinculado y resistir a la economía capitalista.

Palabras clave: Agricultura, campesinos, medios de vida, hogar, tipología, Andes.

\section{INTRODUCTION}

Although the small-scale farming households (i.e., the peasantry) may make up a small proportion of the world's population, the peasantry still constitutes nearly two-fifths of humanity (Weiss, 2007, cited by van der Ploeg, 2018). This implies that around 2.2 billion agrarian household members are living, producing, consuming, and struggling to maintain their livelihoods built upon a peasant way of farming. Therefore, it cannot be argued that the peasantry is a phenomenon related to the past; on the contrary, recent research showed that "today's world is witnessing a

\footnotetext{
${ }^{1}$ More than 250 million peasant farms reappear in China, while also in Brazil the rural exodus from the countryside to towns was reversed through a massive movement of hundreds of thousands of poor people leaving the dangerous favelas for
}

massive, albeit highly, varied processes of repeasantization" (van der Ploeg, 2013) ${ }^{1}$.

In world agriculture, three different modes of farming can be discerned: a peasant, an entrepreneurial, and a largescale corporate (or capitalist) mode of farming. First, the peasant way of farming is built upon labor, which is primarily provided by the family, and in which land and other means of production are owned by the family and of which multi-functionality is a central feature. Second, entrepreneurial agriculture is highly specialized and is completely oriented to markets, and entails partial industrialization of the labor process. Third, large-scale corporate (or capitalist) farming is characterized by a

going toward the countryside, leading to an increase of more than 400.000 newly created peasant farms, covering an area of 32 million hectares (van der Ploeg, 2013). 
labor force that consists of salaried (or piece-rate) workers, applying an agro-export model, and willing to transfer from one to another location whenever profit rates require a transfer. This corporate farm takes the shape of an extensive web of mobile farm enterprises.

In reflecting critically on the way's peasant farms maintain their livelihoods, we refer to the Chayanovian approach (Chayanov, 1974) of studying peasant farms and connect it with a critical reflection on livelihood studies. Central to the Chayanovian approach in studying peasant modes of farming is the observation that the peasant farm is conditioned and affected by the capitalist context in which it is operating, although it is not directly governed by it. Instead, it is governed by a set of balances through which it orders the way labor force is used, the ways fields are cultivated, the products are consumed or sold, the cattle are bred, and irrigation works constructed. Therefore, a core issue of the Chayanovian approach of peasant studies is the presence of this double aspect within the peasant mode of farming. On one hand, the peasant unit is linked to the capitalist economy in which there are many pressures to draw the peasant unit into commodity production and is powerfully directed by the capitalist world's economic demands. On the other hand, the peasant unit maintains a form of autonomy and operates in a way that is distinctively different from the way in which capitalist farm enterprises are managed. In short, peasant farms are part of the dominant capitalist system, but it is also true that peasant farms are a subordinated part of that economy and that the millions of peasant farms resist and develop other forms of value production. Moreover, the peasant farm in itself is not a capitalist unit of production; it is not grounded on the capital-labor relation; capital in the peasant farm is not Capital in the Marxist sense (of the capital-labor relation), it is rather "a patrimony" composed of the soil, animals, buildings, machines, all directly owned by the family. Besides, labor in the peasant unit is not wage labor but rather family labor. Through the balances the peasant farm creates specific forms of relations (internal and external) based on which they maintain their livelihoods. Frictions with the dominant capitalist economy are generated and produce alternatives which may even indicate solutions to some of the general problems' humankind is facing.

Review of the farming systems in the Paute basin of Ecuador indicated that the most dominant form of farming is the peasant mode, while the entrepreneurial and largescale corporate farming style are more or less absent. Furthermore, the review reveals that three sub-forms of the mode of peasant farming is present, in which the production of food and reproduction of their livelihoods take place in different ways. Indeed, the empirical data of the Paute basin of Ecuador shows that the peasant mode of farming contain types of households differently shaped around the availability of labor force at the farm and the specific connections with the external world. This paper aims to highlight how the peasant farms operate differently in organizing the production and reproduction in the Paute basin of Ecuador. The first objective of this paper is to describe the demographic, socio-economic, and agricultural characteristics of three research sites in the basin, their land-use practices, and the environmental perceptions of the surveyed persons in the research areas. The analysis of the differentiation in the variables among surveyed persons led to the awareness that different modes of peasant farming exist. The second objective of the research project is to identify a typology of peasant household based on their specific organizational forms of producing and reproducing their livelihoods. The basic hypothesis of the research project is that we expect a diversity of livelihood strategies among the surveyed persons due to the diversity of their demographic and socio-economic characteristics (including their migratory patterns), their agricultural and land-use practices, and environmental perceptions.

\section{STUDY AREAS AND COLLECTED INFORMATION}

\subsection{The study area: The Paute basin}

The Paute basin of Ecuador covers an area of 5,200 km² (i.e., $1.83 \%$ of Ecuador's total area) and is located in the provinces of Azuay and Cañar (see Figure 1). According to INEC $(2010)^{2}$ the total population of the basin varies around 650,000 (i.e., $4.06 \%$ of Ecuador's population) of which - since the 1980s - hundred thousand inhabitants migrated, and the subsequent transfer of money by the migrants culminated in an improvement of the socioeconomic status of the local population (Jokisch, 2002). Agriculture is an important activity in the Paute region, although for the national economy the production of electricity in the Paute basin - that accounts for $35 \%$ of the national electricity - is more important. The research summarized in this article focused on the analysis of the livelihood strategies of peasant households within the following three areas of the Paute basin (see Figure 1):

- Pichacay area located in Santa Ana parish, near Cuenca city in Azuay province,

- Caldera area located in Javier Loyola parish, near

Déleg city in Cañar province, and

- Llavircay area located in Rivera parish, near Azogues city in Cañar province.

\section{Pichacay (Santa Ana parish)}

Pichacay is located in Santa Ana parish that belongs to the rural parishes of the city of Cuenca, located in the Azuay province, at a distance of $16 \mathrm{~km}$ from Cuenca, and has a population of 5.366 persons of which 1,427 persons lives in the Pichacay area cultivating 460 ha of the Santa Ana parish. Since $27 \%$ of the total Santa Ana Parish live in the Pichacay area it is clear that the Pichacay area is densely populated, particularly young people with an average age of 31 years, and a gender division of $27 \%$ male and $26 \%$ female. Moreover, according to INEC data (2010), there is still a recent relatively low migration rate, $3.22 \%$ of the total population, in the Pichacay site. The proximity of the city stimulated Santa Ana's population to establish their economic activities in the city. Notwithstanding, agriculture remains an important economic activity in the Pichacay area representing $23 \%$ of the economic activities (INEC, 2010), while the other $77 \%$ are dedicated to delivering labor force and services, carrying out trade activities, and other professions. As stated by Vandenberghe \& Vanacker (2008) resulted overgrazing

\footnotetext{
${ }^{2}$ National Institute for Statistics and Census, Ecuador.
} 


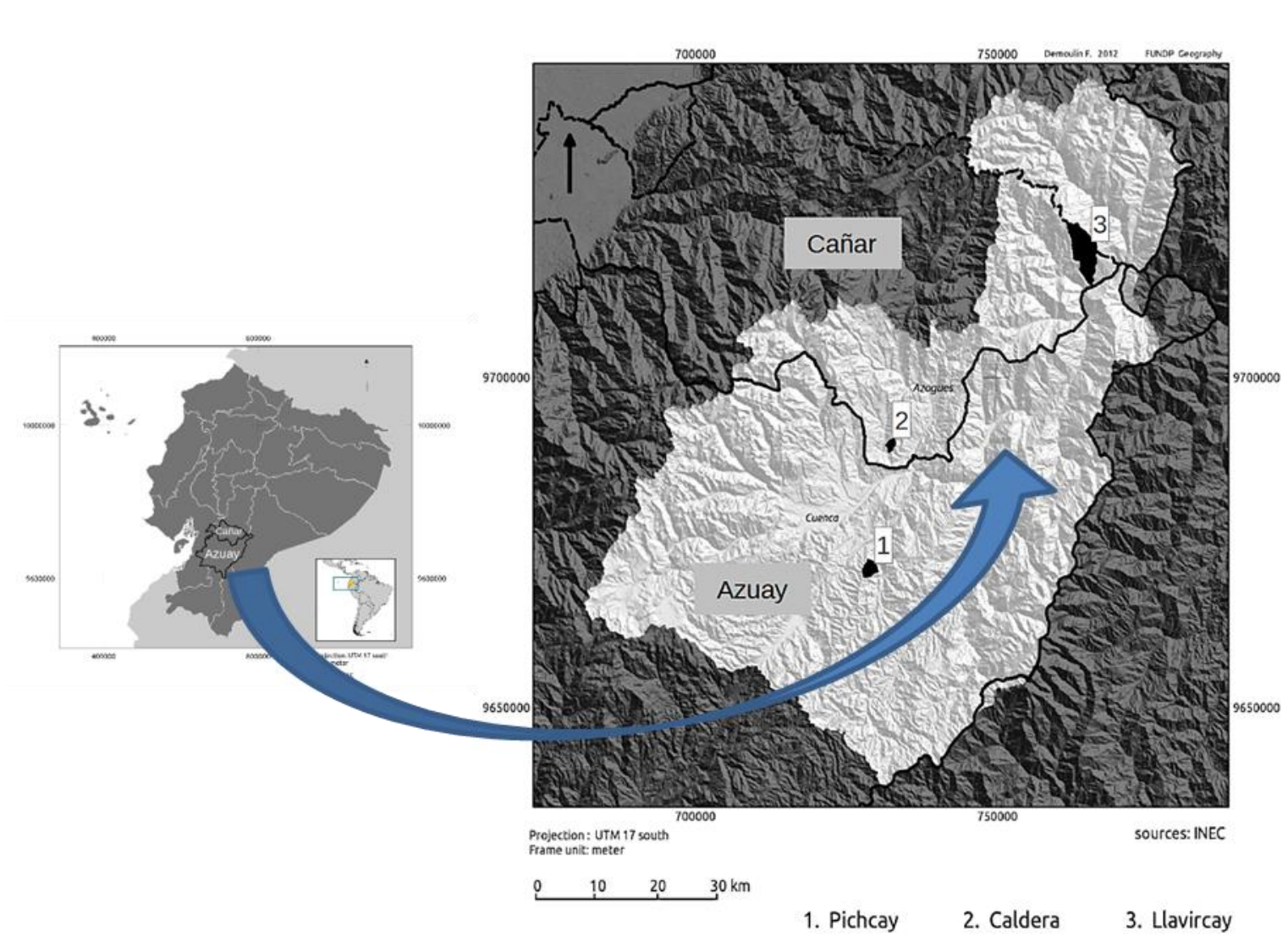

Figure 1. Paute basin in Ecuador with the location of the three study areas.

and intensive cultivation of the poor soils in severe land degradation, and widespread poverty amongst the rural population. Besides, primary and secondary forest depletion is noticeable across Santa Ana parish as a consequence of the construction of houses, local roads, and Cuenca's city landfill-site. The decline in forest stand is also caused by soil erosion (badlands, landslides, and deep and shallow gullies) primarily provoked by flooding.

\section{Caldera (Javier Loyola parish)}

Caldera site is located in Javier Loyola parish, which belongs to the rural parishes of Déleg city in Cañar Province, relatively close to the cities of Azogues (10 km) and Cuenca $(22 \mathrm{~km})$. This area is relatively low populated; and from the 6,807 parish inhabitants only 586 live in the Caldera study area, which means that only $9 \%$ of the parish population is located in this area ( $8 \%$ for male and $9 \%$ for female) (INEC, 2010). Concerning the age structure, the most representative population living nowadays in the Caldera study area corresponds to persons with ages falling between five up to 39 years old. So also, in this study area, there is a young average age structure. Migration in Javier Loyola parish started quite earlier (the ' $80 \mathrm{~s}$ ) and was most likely linked to land abandonment. Nevertheless, currently, the migrant population still represents $7.51 \%$ of its total population (INEC, 2010). The proximity to the cities also pushed the Javier Loyola population to establish their economic activities in these cities. Indeed $66 \%$ of the total economic activities are no-agricultural activities of which some of these activities are performed in Azogues and Cuenca. However, agriculture remains the most important economic activity in Caldera site (34\%), notwithstanding the cultivation of crops and the rearing of cattle is not that easy due to soil degradation and the absence of irrigation facilities. Most lands are dry and affected even by erosion. Although the rather difficult conditions are the parish local organizations strong, mainly based around the socalled "water boards" that represent about 1,500 members. Besides, the parish infrastructure is highly deficient, secondary and third-order roads are poorly maintained what contributed to an increase in flooding events in some parts of the parish. The current situation is problematic although efforts are made to restore the natural vegetation, and reforestation is currently underway.

\section{Llavircay (Rivera parish)}

The Llavircay study area is located in Rivera belonging to the rural parishes of Azogues city in Cañar province, is highly populated, and 578 persons from the 1,542 parish inhabitants $(37 \%)$ live in the Llavircay study area, of which $39 \%$ are male and $36 \%$ female. Concerning the age structure, the most representative population living nowadays in Llavircay site correspond to the young age group between 1 to 24 years. According to INEC data (2010), migration in the Llavircay site is relatively low; representing $2.77 \%$ of its total population and a general low migration rate in this parish is expected. Rivera is quite an isolated parish due to its location (45 km from Azogues and $78 \mathrm{~km}$ from Cuenca) and possesses specific geographic characteristics (topography, natural environment, weather conditions). The Rivera population develops mainly its economic activities in the parish, 
mostly in agriculture and related activities, representing in the Llavircay site $80 \%$ (INEC, 2010) of the total population activities. Agriculture production is mostly destined for family consumption purposes, while the most important income source for the Rivera population is the conversion of livestock and pasture products. Unfortunately, these activities led to high deforestation by the burning of primary and secondary forest. Across the study area, some spots of soil erosion and forest depletion are caused by flooding. The parish local organization is weak, mainly represented by local community members who are part of the main "parish board". However, the board is not constantly operating due to the large extent of the parish. Moreover, "a waterboard" does not exist since water availability is not a problem, on the contrary, due to constant heavy rains, flooding and landslides occur frequently. The parish infrastructure is poor although thanks to the Paute hydroelectric water plant good primary and secondary roads are present. Unfortunately, due to the hydroelectrical plant many new environmental and social problems surfaced, such as drastic changes in the landscape while the construction and utility roads around the Paute/Mazar plant enhanced migration (CGPaute, 2006). According to Jokisch \& Lair (2002) was this area largely untouched and forested till the ' 70 s, and currently became the Rivera parish part of one of the largest ecological protected areas in Ecuador (the "Sangay National Park"), which led to the establishment of various private (national and international NGO's) and public institutions (Ministry of Environment, and some universities) of which it is not known yet whether and if so which social relations these institutions have established with the peasant modes of farming in this parish.

\subsection{Outline of the conducted surveys}

The population survey (called the 3-Paute) research areas (Table 1) (Vanegas, Demoulin, \& Henry, 2012) was conducted in the framework of a joint research project between the University of Namur (Belgium) and the University of Cuenca (Ecuador). Based on the 2010 population census sector maps (INEC, 2010), the surveyed households were selected by simple random sampling. A list of houses was obtained in each study area and a random rank was assigned to each home. The questionnaires included (i) environmental topics related to agricultural practices, land-use change, land degradation; (ii) socio-demographic topics related to migration (i.e., duration, destination, contacts and remittances), household composition and gender roles; (iii) socioeconomic topics related to consumption, the level of education, economic activities; and (iv) the perception of the left-behind on the environmental issues. The sample contained 1,113 individual bibliographies representing $43 \%$ of the total population, respectively 390 persons were surveyed in Pichacay, 365 in Caldera and 358 in Llavircay. The surveyed persons belonged to 78 of the 358 household in Pichacay (22\%), 90 out of 165 in Caldera (55\%), and 71 out of 133 households in Llavircay (53\%).

\section{DESCRIPTION OF COLLECTED INFORMATION}

\section{Demographic characteristics}

The three research areas differ in their population densities. The Pichacay study area is characterized by a relatively high population level of $27 \%$ of the Santa Ana parish population, while the Caldera study area is relatively low populated by only $9 \%$ of the Javier Loyola parish community. The Llavircay study area is also characterized by a relatively high population level of $37 \%$ of the Rivera parish population. All the three research sites have in common a young average age structure that circles around 31 years, while the gender division consists of a slight dominancy of female over the male population, with 756 female persons (53\%) in Pichacay, 320 females $(55 \%)$ in Caldera, and 299 females $(52 \%)$ in Llavircay (see Table 2). The demographic characteristics of the households depict indirectly the availability of the family labor force (Perret, Anseeuw, \& Mathebula, 2005; Bidogeza, Berentsen, De Graaff, \& Oude Lansink, 2009). Variables as the average age structure, the gender division, and number of persons are all important variables, not only for the strength of the household labor force, but also influence the livelihood-related decisions of the household (Ellis, 1993), and particularly the decision-making processes in the family unit concerning the management of land-use practices and their relations with the external world.

Table 1. Number and proportion of the population and households surveyed, by study area.

\begin{tabular}{ccccc}
\hline Total parish population & $\begin{array}{c}\text { Study area population } \\
(\#, \%)\end{array}$ & $\begin{array}{c}\text { Surveyed population } \\
(\%)\end{array}$ & $\begin{array}{c}\text { Total number of } \\
\text { households* }\end{array}$ & $\begin{array}{c}\text { Surveyed households } \\
(\%)\end{array}$ \\
\hline Santa Ana $(5,366)$ & Pichacay $1,427(27 \%)$ & $390(27 \%)$ & 358 & $78(22 \%)$ \\
Javier Loyola (6,807) & Caldera (586, 9\%) & $365(62 \%)$ & 165 & $90(55 \%)$ \\
Rivera (1,542) & Llavircay (578,37\%) & $358(62 \%)$ & 133 & $71(53 \%)$ \\
Total $(13,715)$ & $2,591(19 \%)$ & $1,113(43 \%)$ & 656 & $239(36 \%)$ \\
\hline
\end{tabular}

*Source: INEC (2010)

Table 2. Demographic characteristics of the three study areas.

\begin{tabular}{lccc}
\hline \multicolumn{1}{c}{ Population } & $\begin{array}{c}\text { Pichacay } \\
\text { (Santa Ana parish) }\end{array}$ & $\begin{array}{c}\text { Caldera } \\
\text { (Javier Loyola parish) }\end{array}$ & $\begin{array}{c}\text { Llavircay } \\
\text { (Rivera parish) }\end{array}$ \\
\hline Total & 1,427 & 586 & 578 \\
Male & $671(47 \%)$ & $266(45 \%)$ & $279(48 \%)$ \\
Female & $756(53 \%)$ & $320(55 \%)$ & $299(52 \%)$ \\
Percentage of parish population & $27 \%$ & $9 \%$ & $37 \%$ \\
Age (average) & 31 & 31 & 31 \\
\hline
\end{tabular}

Source: INEC (2010) 
Table 3. Share agricultural versus non-agricultural activities in the three study areas.

\begin{tabular}{lccc}
\hline \multicolumn{1}{c}{ Economic activities $^{3}$} & $\begin{array}{c}\text { Pichacay } \\
\text { (Santa Ana parish) }\end{array}$ & $\begin{array}{c}\text { Caldera } \\
\text { (Javier Loyola parish) }\end{array}$ & $\begin{array}{c}\text { Llavircay } \\
\text { (Rivera parish) }\end{array}$ \\
\hline Agricultural & $129(23 \%)$ & $99(34 \%)$ & $178(80 \%)$ \\
Non-agricultural & $424(77 \%)$ & $195(66 \%)$ & $45(20 \%)$ \\
\hline Source: INEC $(2010)$ & & &
\end{tabular}

Table 4. Out-migration from the three research areas.

\begin{tabular}{lccc}
\hline \multicolumn{1}{c}{ Out-migration $^{4}$} & $\begin{array}{c}\text { Pichacay } \\
\text { (Santa Ana parish) }\end{array}$ & $\begin{array}{c}\text { Caldera } \\
\text { (Javier Loyola parish) }\end{array}$ & $\begin{array}{c}\text { Llavircay } \\
\text { (Rivera parish) }\end{array}$ \\
\hline Male & $40(87 \%)$ & $29(66 \%)$ & $13(81 \%)$ \\
Female & $6(13 \%)$ & $15(34 \%)$ & $3(19 \%)$ \\
Percentage of parish population & $3.22 \%$ & $7.51 \%$ & $2.77 \%$ \\
\hline
\end{tabular}

Source: INEC (2010)

\section{$\underline{\text { Socio-economic characteristics }}$}

The proximity to major cities affects the diversity of economic activities, and is relevant for the division between agricultural and non-agricultural exercises ${ }^{5}$. This is particularly true for Pichacay and Caldera where only 23 and $34 \%$ of the population are involved in agriculture, whereas $80 \%$ of the population in Llavircay is engaged in cattle rearing and the cultivation of forage and crops. The share of non-agricultural activities, particularly carried out in the nearby cities is subsequently $77 \%$ for the Pichacay people, $66 \%$ for Caldera and $20 \%$ for Llavircay (see Table 3). Another important socioeconomic variable that influences the livelihood strategies in the three research areas is the presence and percentage of the out-migration, which is $3.22 \%$ of the total Pichacay population, $7.51 \%$ in Caldera and $2.77 \%$ in Llavircay (see Table 4). In addition, a differentiation can be noted concerning the participation of the residents in waterboards and trade organizations (see Table 5). In Pichacay there is water availability and no water boards exist, while in Caldera - which also deals with a lack of water - strong Rivera Parish "waterboard" organizations do exist. In Llavircay parish is the situation different; there is not a lack of water but rather an excess of water due to heavy rainfall leading to serious problems with flooding, causing landslides. Nevertheless, no "waterboard" does exist in this parish ${ }^{6}$. There are also no important irrigation works neither in Pichacay and Caldera where a lack of water exists nor in Llavircay dealing with an excess of water. Therefore, no communal plans have been set up to manage collectively the water flows. In all the three research sites, there is also weak communal participation in trade organizations. The interviewed persons of Llavircay explained this by stressing that due to the long distance between the various households there is no interest in participating in local (trade) organizations (see Table 5). However, no participation in trade organizations within the other parishes exists in which physical distance is apparently not a problem.

\section{Agriculture practices}

Land preparation, the use of natural and chemical fertilizers and other agrochemicals (see Table 5) differs between the three study areas. In Pichacay the peasant household uses their family labor force for preparing manually their lands, while in Caldera and Llavircay, the peasants apply both animal and sometimes mechanized land preparation. The use of natural fertilizers is dominant in Pichacay, while in Caldera and Llavircay, more agrochemicals are used such as pesticides and fertilizers. The three research sites are characterized by either crop cultivation or cattle rearing or by doing both (see Table 5). In the Pichacay research site intensive cultivation occurs on poor soils and cattle overgraze the pastures. Also, in Caldera do the inhabitants have a tough job due to the drylands and soil degradation, hindering crop cultivation and cattle rearing. Agricultural production is mostly destined for family consumption and local trade in Llavircay, while the most important source in this study area is the conversion of livestock and pasture products into salable products. In all three-research sites are the inhabitants confronted with soil erosion, either by flooding (Pichacay), droughts (Caldera), or deforestation for the construction of houses and large infrastructure (Llavircay).

\section{Environmental perceptions}

In all three-research sites, low attention is paid to environmental issues. In Pichacay, the survey showed that there is an awareness of the severe land degradation due to the overgrazing and intensive cultivation, while in Caldera awareness of the loss of natural vegetation and deforestation led to initiatives of restoration of the natural vegetation and reforestation. In the Llavircay study area, the expansion of the agricultural frontier into the secondary and primary forest resulted in high deforestation. Moreover, the introduction of the hydroelectric plant in the Paute area led to drastic landscape changes, the construction of utility roads to the plant which facilitated migration.

\footnotetext{
3 Only economically active people over the age of 10 are considered (INEC, 2010).

4 A migrant is considered any person who migrated abroad between November 2001 (VI national census) and November 2010 (last national census) (INEC, 2010).

5 "Agricultural activities" in Ecuador consist of agriculture, livestock, forestry, hunting, and/or fishing. "Non-agricultural activities" are all activities not related to agricultural activities (INEC, 2012).

${ }^{6}$ Due to its closeness to the city of Cuenca, an important part of the Pichacay population have access to water (around $40 \%$ according to INEC 2010), which may explain the absence of a water board in this area.
} 
Table 5. Differentiations in five variables and various characteristics in three research sites.

\begin{tabular}{|c|c|c|c|}
\hline $\begin{array}{l}\text { Total and surveyed population and households (3- } \\
\text { Paute survey) }\end{array}$ & Pichacay & Caldera & Llavircay \\
\hline Total and surveyed persons & $1,427 / 390$ & $586 / 365$ & $578 / 358$ \\
\hline Total and surveyed households & $358 / 78$ & $165 / 90$ & $133 / 71$ \\
\hline $\begin{array}{l}\text { Demographic characteristics } \\
\text { (3-Paute survey) }\end{array}$ & Pichacay & Caldera & Llavircay \\
\hline 1. Average Age & 31 & 31 & 31 \\
\hline 2. Gender Composition & $\begin{array}{l}671 \mathrm{M}(47 \%) \\
756 \mathrm{~F}(53 \%)\end{array}$ & $\begin{array}{l}266 \mathrm{M}(45 \%) \\
320 \mathrm{~F}(55 \%)\end{array}$ & $\begin{array}{l}279 \mathrm{M}(48 \%) \\
299 \mathrm{~F}(52 \%)\end{array}$ \\
\hline 3. Population density & High $(27 \%)$ & Low $(9 \%)$ & High $(37 \%)$ \\
\hline $\begin{array}{l}\text { Socio Economic characteristics } \\
\text { (INEC, 2010) }\end{array}$ & Pichacay & Caldera & Llavircay \\
\hline 4. Proximity Cities & Cuenca - $16 \mathrm{~km}$ & $\begin{array}{l}\text { Azogues }-10 \mathrm{~km} \\
\text { Cuenca - } 22 \mathrm{~km}\end{array}$ & $\begin{array}{l}\text { Azogues }-45 \mathrm{~km} \\
\text { Cuenca }-78 \mathrm{~km}\end{array}$ \\
\hline 5a. Share Agricultural Activities & $129(23 \%)$ & $99(34 \%)$ & $178(80 \%)$ \\
\hline 5b. Share Non-Agri. Act. & $424(77 \%)$ & $195(66 \%)$ & $45(20 \%)$ \\
\hline $\begin{array}{l}\text { 6. Out-migration } \\
\text { (in } \% \text { of parish population) }\end{array}$ & $\begin{array}{c}3.22 \% \\
40 \mathrm{M} / 6 \mathrm{~F}\end{array}$ & $\begin{array}{c}7.51 \% \\
29 \mathrm{M} / 15 \mathrm{~F}\end{array}$ & $\begin{array}{c}2.77 \% \\
13 \mathrm{M} / 3 \mathrm{~F}\end{array}$ \\
\hline 7. Participation in local water boards & $\begin{array}{l}\text { Water availability, no } \\
\text { boards }\end{array}$ & $\begin{array}{l}\text { Lack of water and } \\
\text { strong boards }\end{array}$ & $\begin{array}{l}\text { Surplus of water, no } \\
\text { boards }\end{array}$ \\
\hline 8. Participation in agricultural trading organizations & None & None & None \\
\hline $\begin{array}{l}\text { Agricultural practices - Drudgery } \\
\text { (3-Paute survey) }\end{array}$ & Pichacay & Caldera & Llavircay \\
\hline 9. Cultivation of crops ${ }^{7}$ and cattle rearing & Both & Both & Both \\
\hline 10. Subsistence & High & Medium & $\begin{array}{c}\text { Priority on family } \\
\text { consumption and local } \\
\text { trade }\end{array}$ \\
\hline 11. Marketing & Yes & Yes & $\begin{array}{l}\text { Converting livestock } \\
\text { and pastures production } \\
\text { into commercially } \\
\text { products }\end{array}$ \\
\hline $\begin{array}{l}\text { 12. Preparation of land (manual, animal traction, } \\
\text { mechanized) }\end{array}$ & Manual & Animal and mechanized & Animal and mechanized \\
\hline 13. Use natural fertilizers & Dominant & Weak & Weak \\
\hline 14. Use chemicals (fertilizers and pesticides) & Weak & Dominant & Dominant \\
\hline 15. Construction irrigation works & Weak & Weak & No \\
\hline Land Use Practices (3-Paute survey) & Pichacay & Caldera & Llavircay \\
\hline 16. Land use problems & $\begin{array}{l}\text { Intensive cultivation, } \\
\text { poor soils and } \\
\text { overgrazing pastures }\end{array}$ & $\begin{array}{l}\text { Lack of water and soil } \\
\text { degradation }\end{array}$ & $\begin{array}{l}\text { Soil erosion and forest } \\
\text { depletion }\end{array}$ \\
\hline 17. Soil erosion & $\begin{array}{l}\text { Due to flooding and } \\
\text { house constructions }\end{array}$ & Due to lack of water & Due to deforestation \\
\hline 18. Use of firewood (gathering and/or deforestation) & Gathering & Deforestation & Deforestation \\
\hline $\begin{array}{l}\text { Environmental Perceptions } \\
\text { (3-Paute survey) }\end{array}$ & Pichacay & Caldera & Llavircay \\
\hline 19. Not an issue & Yes & Yes & Yes \\
\hline 20. Awareness of Issues ${ }^{8}$ & Land degradation & $\begin{array}{l}\text { Loss of natural } \\
\text { vegetation; } \\
\text { deforestation }\end{array}$ & $\begin{array}{c}\text { Expansion of } \\
\text { agriculture in secondary } \\
\text { and primary forest; } \\
\text { deforestation }\end{array}$ \\
\hline
\end{tabular}

\section{TYPOLOGY OF THE PEASANTS LIVELIHOOD STRATEGIES}

In rural sociology, typologies have mainly been used to distinguish the social and economic characteristics of farming (Whatmore, 1994), and its application at the farm level has been extended to the level of the rural household in the context of rural development (Whatmore, 1994; Laurent, van Rooyen, Madikizela, Bonnal, \& Carstens, 1998; Perret, Carstens, Randela, \& Moyo, 2000). Within this context, Perret \& Kirsten (2000) define a typology as a quantitative or qualitative procedure that categorizes households or individuals into homogenous groups with similar constraints and incentives, and which are expected to respond to external influences in a similar fashion.

In order to build a typology of the peasants' livelihood strategies across the three research areas a data-analysis process was applied, in which we clustered, reduced and standardized the multivariate data set of the abovementioned variables by applying, successively: (1) the technique of combining principal component and cluster analysis; (2) the technique of factor analysis for mixed

\footnotetext{
7 Reference is made to maize \& beans, potatoes, wheat, fruit, vegetables.

8 Possible environmental issues, to which is referred in Table 5, are: Landslides, Environment Pollution, Burning Vegetation Forest, Poor Agric. Irrigation, Flooding, Low Agric. Production, Poor soil fertility, Soil erosion, Deforestation, Soil pollution.
} 
data (FAMD, see Husson, Josse, Lê, \& Mazet, 2009); and (3) the multivariate technique of Hierarchical Clustering on Principal Components (HCPC, Husson et al., 2009). Given the multivariate nature of the collected data, multivariate statistical techniques available in the FactoMineR package (Husson et al., 2009), part of the $\mathrm{R}$ software program (Version 3.0.0, R Team, 2007), were applied.

The empirical data show that the different levels of labor force availability, within each family unit, implies that each peasant unit of production aims to balance its laborforce availability with the family's demand for consumption as well as to balance the extra work required to increase total production, with the wish to keep up a quality of life and reduce the drudgery and hardship of long working days. Moreover, it became clear that the peasant family units also aim to balance the use of resources that are produced and reproduced on the farm itself (the internal resources) with the use of external resources acquired on local and regional markets. This quest to balance the use of internal and external resources is also related to the general effort of the family unit to balance its wish to remain relatively autonomous in their decisions about the production and reproduction of their farming unit and the socio-economic need and pressure to install relations with external institutions, such as research institutions and trade organizations, which may raise their productivity and incomes but also enhance their dependency on using resources for the upstream and downstream side of the farming, which implies a reduced autonomy in organizing the work at their farming unit.

By applying the previously mentioned data analysis techniques, the empirical data showed that three overlapping types of peasant's livelihood strategies can be discerned in which the peasant families try to create a certain balance between contrasting goals. In the following paragraphs, we present the three different but also overlapping forms of peasant households that surfaced from the analysis in the three research sites.

\subsection{Type 1: The subsistence households}

This type of peasant household refers to those family units with the lowest labor number of family members, it is 1 or 2 adults per household. Children were not considered labor force in this study since most households claim that their children attend school and some extracurricular activities; they only help during their free time and on weekends. In Pichacay belong $62 \%$ of the surveyed families to Type 1 households, $52 \%$ in Caldera and $60 \%$ in Llavircay, implying that these peasant units have first of all to balance the rather low labor availability with the various tasks that need to be carried out on the farm. Land preparation by this type of peasant household is primarily manual, getting less attention compared with the manual land preparation in the other two types of peasant households (see Table 6). The reason for this might be that the limited labor force - together with the many tasks to be carried out by the family members - urges the family unit to make specific choices in using and distributing the limited available labor force across the many activities that have to be carried out.

Economically these households are highly dependent on subsistence agriculture based on cattle rearing and the cultivation of crops. Often priority is given to rear the cattle above crop cultivation. However, whenever subsistence cropping is practiced than a gender (re-) division of tasks takes place in which labor-demanding crops such as potatoes and fruit are generally, the responsibility of male adults, while less-demanding tasks, such as vegetable growing, and cattle rearing are traditionally managed by female adults. Given the precarious economic situation of these households and its focus on subsistence agriculture, the households try to diversify their economic activities into non-agricultural activities, although in practice out-migration of the labor force is low due to the lack of resources that prevents sending family members abroad. Other characteristics of these family units are the lack of using external agricultural inputs, while also membership in agricultural

Table 6. Three types of the peasants' livelihood strategies.

\begin{tabular}{|c|c|c|c|}
\hline Variables & Type 1 & Type 2 & Type 3 \\
\hline \multicolumn{4}{|l|}{ Demographic } \\
\hline - Age of household head (mean) & 55 years & 29 years & 47 years \\
\hline - Number of adults per household (mean) & $1-2$ & $3-5$ & $>5$ \\
\hline \multicolumn{4}{|l|}{ Socioeconomic } \\
\hline - Agricultural activity & Truly relevant (subsistence) & $\begin{array}{l}\text { Relevant (subsistence and } \\
\text { regional trading) }\end{array}$ & $\begin{array}{l}\text { Relevant (large-scale cattle } \\
\text { rearing and cropping for } \\
\text { local and regional trade) }\end{array}$ \\
\hline - Migration (out \& in) & Not relevant & Low relevance & Relevant \\
\hline - Membership to local water boards & Truly relevant & Low relevance & Truly relevant \\
\hline $\begin{array}{l}\text { - Membership to local agriculture trading } \\
\text { organizations }\end{array}$ & Not relevant & Not relevant & Low relevance \\
\hline \multicolumn{4}{|l|}{ Agricultural practices } \\
\hline - Manual land preparation & Low relevance & Relevant & Relevant \\
\hline - Land preparation by animal traction & Not relevant & Low relevance & Relevant \\
\hline - Mechanized land preparation & Not relevant & Low relevance & Relevant \\
\hline - Use of pesticides & No pesticides & Chemical (low relevance) & Chemical (relevant) \\
\hline \multicolumn{4}{|l|}{ Land use } \\
\hline - Potatoes & Not relevant & Low relevance & Relevant \\
\hline - Fruit & Low relevance & Low relevance & Relevant \\
\hline - Cattle & Low relevance & Relevant & Truly relevant \\
\hline - Firewood & Local forest (truly relevant) & Local forest (truly relevant) & Local forest (truly relevant) \\
\hline Environmental perceptions & Not relevant & Not relevant & Not relevant \\
\hline
\end{tabular}


or trading organizations is hardly considered, which may be related to their focus on subsistence agriculture and self-consumption of their products. In contrast, membership in the local water board is considered highly relevant which indicates that these households give priority to use their limited labor force to nearby-problems of their livelihoods such as the presence of drylands. For the same reason also the extraction of firewood from the local forests is considered relevant, while general environmental issues are hardly taken into consideration. It is clear from the empirical data that the struggle for the day-to-day survival gets all the attention, and the limited available labor force is used to balance the various requirements that need to be fulfilled to maintain the functioning of the peasant household.

\subsection{Type 2: The growing and mid-advantaged households}

This type of peasant household is characterized by the presence of a mini-capacity of particularly young household heads, varying in age between 20 and 39 years, and an innovative labor-force (Martin, 2005). In Pichacay belong $43 \%$ of surveyed households to Type 2, $24 \%$ in Caldera, and $25 \%$ in Llavircay. These households are inclined to seek technical assistance and new trading options, even trading out of their parish if necessary, reducing their need to belong to local trade organizations. Indeed, these households are characterized by extremely poor levels of community organization (see Table 6). Rather, there is a trend that each household aims to solve their problems individually, and for example seek to install individually new marketing relations. The main way for these households to improve their incomes is by taking cattle rearing beyond their subsistence level and convert their pasture products into commercial products for regional markets. Within these households, cropping remains a secondary activity; they are more inclined to extend the cattle rearing instead of focusing on cropping. Nevertheless, manual land preparation is rather important for these households. Only from time to time, these households can afford to rent animal traction or machinery because the rather limited household budgets are mostly allotted to satisfy the elementary family needs. The research data also show a high level of firewood extraction from local forests, which together with their focus on preparing manually illustrate the family's tendency to reduce as much as possible the production costs. However, probably inspired by their trust in new technological developments these households do purchase agricultural inputs such as chemical pesticides. In general, these family units strive to raise their income by establishing relations with institutions upstream and downstream of the peasant household, which also implies that these family units often face high expenses, which prevent them to send family members abroad. Indeed, migration remains rather restricted in this type of household. Ultimately, data analysis showed that these households do not bother much about environmental issues.

\subsection{Type 3: The longstanding and most-advantaged households}

This type of peasant households refers to those family units with the highest availability of labor force (more than 5 adults per household) as well as having the option of hiring extra labor, present in Pichacay (10\% out of the total surveyed families), Caldera (8\%), and Llavircay (9\%). These households represent longstanding rural families of the Paute catchment practicing large-scale cattle rearing for dairy products and cropping for local and regional trade (see Table 6). In other words, they are strongly market-oriented. When the socio-economic situation permits, the household invests primarily in increasing the herd size (increasing their family patrimony) leaving cropping as a secondary income source. As the herd size increases then the daily care of the cattle can no longer be covered by household members (female adults and children in traditional and subsistence Andean agriculture). The farm is managed by the head of the household who hires extra labor to cover the labor shortfall. Wives and children shift their responsibilities towards the cultivation and cattle rearing for household consumption while larger-scale production for trading purposes becomes the responsibility of the head of the household becoming the (entrepreneurial) manager of the unit. The relatively large-scale form of agriculture practiced in this type of household also pushes the household heads to participate in water boards helping to ensure proper water supply and to become involved in regional and even national trade organizations, attributing a low level of importance to local trading organizations.

The research data also show that this type of household diversify their (on-farm) economic activities for which they hire extra labor. Moreover, the socioeconomic status allows them to finance costly illegal trips abroad by household members, stimulating the out-migration from the rather economically well standing family units. Concerning the agricultural practices manual land preparation is considered relevant viewing the availability of a high labor force as well as the option of hiring extra labor. These households invest heavily in agricultural inputs such as chemical pesticides, and the use of firewood is also important for them leading to their involvement in the deforestation of the primary and/or secondary forest in the Paute catchment. Last but not least, research results show that the awareness of environmental issues within this group of households is weak. It is clear that environmental issues have been overshadowed by the households' main objectives of large-scale cattle rearing and crop production.

\section{DISCUSSION}

Based on the regional diversity, we distinguished in the Paute basin in Ecuador three types of peasant farming families that organize their lives in a specific way. The different types of farming families use a specific organizational plan (Chayanov) as a guide for the many farm activities which they perform in a specific way. The organizational plan (or script) of the farm is primarily based on the on-farm disponibility of a variety of sources. However, the empirical study revealed that the diversity in types of farming families was mainly due to the different amounts of available labor power. As Chayanov noted for Russian agriculture at the beginning of the $20^{\text {th }}$ century, the demographic characteristics of the peasant family play a crucial role in the way in which the farm decides to carry out its productive and reproductive tasks. The Paute basin study also shows that the number of family members and their age structure, it is the presence 
and availability of family labor, also in the $21^{\text {st }}$ century, is the factor farm families in rural areas to a large or small extent prepare the land manually for the cultivation of crops and/or for keeping livestock. In our study, the types of peasant farming families make a different trade-off between the utility that intensive manual tillage yields and the amount of effort that such tillage entails. The peasant households also consider to what extent those extra efforts can or cannot be better focused on other activities such as, for example, the collection of firewood. In fact, the research also showed that peasant families in their own specific way seek a balance between utility and drudgery (Chayanov), the additional hard work that involves manual tillage; a balance that shapes the way in which the peasant farm provides for its livelihood.

A second characteristic of the three types of farming families is their different ways of making a balance between how much of the available labor-power must be dedicated to the cultivation of crops for own consumption, and how much work can be dedicated to the cultivation of crops and products for sale in the local market. The research confirms what Chayanov has called "the balance of labor and consumption". The trade-off is also related to other decisions taken by the peasant family, for example, the decision whether the consumed resources are replaced by re-using farm resources or by purchase external resources. Some households prefer for example to purchase fertilizer and pesticides with the expectation that these external resources would raise the productivity level - despite their additional costs - and would lead to higher revenue. The empirical study showed that the majority of the peasants prefer to maintain the fertility of the soil and the protection of crops against diseases and pests from their own sources. Only a few and often only the financially strong peasant families are able and willing to invest in the purchase of chemical fertilizers and pesticides. In addition, it turned out that young farming families mainly see perspective in the use of new technological developments and take this into account when planning. These considerations of what Chayanov/van der Ploeg has called the balance of internal and external resources are also linked to other considerations such as the wish of the peasant family to remain autonomous and become dependent only to a limited extent on external (market) forces. In short, the peasant family also weighs up the degree of autonomy they want to retain, and whether or not to accept a certain dependence on external forces. In other words, there is also the balance between autonomy and dependence that steers the livelihood strategies of the peasant units.

Another important distinction between the types of farming families is their approach to participate or not in group activities, for example marketing together with their products (dairy products, fruit, etc.) and/or regulating jointly the water scarcity or water abundance by participating in "water boards". Each peasant family unit makes its own assessment, which means that there is indeed a strong differentiation in their participation in collective trade cooperatives and water boards. Besides, it is not surprising that those farmers' families who already market their products themselves on local markets are asking themselves to what extent participation in cooperative activities is beneficial. In general, the empirical study showed that - despite a certain involvement in cooperative activities - the peasant families adopt a rather skeptical attitude with regard to participation in collective trade or water organizations and prefer their individual autonomous position, not only regarding external market forces, but also regarding cooperative institutions to which they are quite reluctant to participate. On the other hand, it appears that joint work in specific circumstances such as harvest are widely spread and accepted. In short, there is continuous winding movement as to whether or not to participate in collective activities whereby a balance is sought between maintaining its autonomy and accepting a certain dependence on the other.

The three different types of farming families clearly show that they follow different roads to maintain their livelihoods and "balance differently" the many and often contrasting business goals. Following the example of Chayanov and van der Ploeg, we would like to emphasize that only the peasant family units themselves understand what considerations they want to make and are the only ones that can decide for themselves whether or not they want to bear the consequences of certain choices - such as whether or not to purchase external sources - or prefer to make a different assessment; an assessment that may also change over time. Indeed, the balances are temporarily decisions made in situations where the families find themselves, and which can change over time. Therefore, the peasant modes of farming are not static but dynamic.

\section{CONCLUSIONS}

This article provides an insight into the different types of peasant livelihoods present in three rural communities of the Paute basin (Ecuador), a topic little addressed in Ecuador or Latin America. By analyzing first-hand collected and census data, three types of peasant households could be distinguished based upon their specific organizational forms of producing and reproducing their livelihoods. The first one is the subsistence households characterized mainly by their need to balance (make specific choices in using and distributing) the limited available labor force across the many on-farm activities, their need to diversify their activities into non-agricultural activities, and the lack of using external agricultural inputs and low out-migration due to lack of resources. The second type is the growing and mid-advantaged households that represent the innovative labor-force inclined to seek technical assistance and new trading options. They show a tendency to reduce as much as possible the production costs, but also do invest in agricultural inputs seeking to increase their profit. Out-migration remains low due to economic limitations. The last type is the longstanding and mostadvantaged households characterized by the highest availability of labor force (not only familial but including the economic possibility of hiring) and a strongly marketoriented approach. As their family patrimony increases (herd size), there is a trend to re-organize their on-farm activities, pushing the head of the household to lead trading (large scale) and become the manager of the unit. Due to their socioeconomic status, out-migration and investment in agricultural inputs are high. In summary, considering our research question, this diversity of livelihood strategies are strongly dependent on a diversity of demographic and socio-economic characteristics 
(including migratory patterns and agricultural and landuse practices) mainly.

A follow-up of peasant studies has hardly been conducted in Ecuador. Our study can be considered as a first step on the intrinsic value and potential of peasant household farms in Ecuador, which we will further investigate at the country scale. For instance, the operation of the Chayanovian balance involves actors being able to interpret rules and specific situations of the singular peasant family and peasant farm, in order to make the appropriate decisions. This raises the fundamental question of gender relations (especially important for the longstanding and most-advantaged households in the Andes). Another familial relation that is decisive for the future of farming concerns is intergenerational renewal and the prospects for youth in agriculture (especially relevant for the growing and mid-advantaged households in the Andes). Last but not least, future research on the peasantry in the Andes should also consider that it is not only the peasant family that is searching for the best possible equilibrium. External agencies (banks, agroindustries, trading, and retail companies, technicians, etc.) are also actively reassessing the different balances in ways that better correspond with their own interests, even if this is unfavorable for the direct producers. In short, the applied Chayonovian approach is characterized by the recognition that these balances are the result of the ongoing power relations in which peasants develop their specific livelihoods.

\section{ACKNOWLEDGEMENTS}

The authors like to express gratitude to the Ecuadorian Andean communities (Pichacay, Caldera and Llavircay) who contributed to this research. Funding for this research was provided by the Belgian CUD commission through the PIC project "Strengthening the scientific and technological capacities to implement spatially integrated land and water management schemes adapted to local socio-economic and physical settings", project formulated and implemented by the Facultad de Ciencias Agropecuarias of the University of Cuenca (Ecuador), the Université Catholique de Louvain, the KU Leuven, and the Université de Namur (Department of Geography), Belgium.

\section{REFERENCES}

Bidogeza, J., Berentsen, P., De Graaff, J., \& Oude Lansink, A. (2009). A typology of farm households for the Umutara Province in Rwanda. Food Security, 1, 321-35.

CGPaute. (2006). Dinámicas socio-económicas rurales en la cuenca del Paute. Consejo de Gestión de Aguas de la Cuenca del Paute. Proyecto de Desarrollo de la Cuenca del Río Paute, Ecuador.

Chayanov, A. (1974). La organización de la unidad económica campesina. Ediciones Nueva Visión, Buenos Aires, 1974. Editada en ruso en 1925 por el Instituto de Investigación Científica de Economía Agrícola de Moscú.
Ellis, F. (1993). Peasant economics: Farm households and agrarian development. Cambridge, UK: University Press.

Husson, F., Josse, J., Lê, S., \& Mazet, J. (2009). FactoMineR: Multivariate exploratory data analysis and data mining with $R$. $R$ package version 1.12. Available at http://factominer.free.fr.

Instituto Nacional de Estadística y Censos (INEC) (2010). VII Censo de Población y V de Vivienda. Resultados definitivos, provincias del Azuay y Cañar. INEC, Quito, Ecuador.

Instituto Nacional de Estadística y Censos (INEC) (2012). Clasificación Nacional de Actividades Económicas (CIIU Rev. 4.0). INEC, Quito, Ecuador.

Jokisch, B. (2002). Migration and agricultural change: The case of smallholder agriculture in highland Ecuador. Human Ecology, 30, 523-550.

Jokisch, B., \& Lair, B. (2002). One last stand? Forests and change on Ecuador's eastern cordillera. Geographical Review, 92(2), 235-256. https://doi.org/10.1111/j.1931-0846.2002.tb00006.x

Laurent, C., van Rooyen, J., Madikizela, P., Bonnal, P., \& Carstens, J. (1998). Household typology for relating social diversity and technical change: The example of rural households in the Khambashe area of the Eastern Cape Province of South Africa. Agrekon, 38(S1), 190208. https://doi.org/10.1080/03031853.1999.9524914

Martin, J. (2005). Los factores definitorios de los grandes grupos de edad de la población: tipos, subgrupos y umbrales. Geo Crítica / Scripta Nova. Revista electrónica de geografía y ciencias sociales, IX(190). Available at http://www.ub.es/geocrit/sn/sn-190.htm

Perret, S., Anseeuw, W., \& Mathebula, F. (2005). Poverty and livelihoods in rural South Africa: Integrating diversity and dynamics of livelihoods. Case studies in Limpopo. Report on theme 1: Strategies for poverty alleviation and food security. Pretoria, South Africa: Post-Graduate School for Agriculture and Rural Development, University of Pretoria.

Perret, S., Carstens, J., Randela, R., \& Moyo, S. (2000). Activity systems and livelihoods in the Eastern Cape Province rural areas (Transkei): Household typologies as socio-economic contributions to a LandCare project. Working Paper 2007-07. Pretoria, South Africa: University of Pretoria / CIRAD, CIRAD Tera num. 2000/28.

Perret, S., \& Kirsten J. (2000). Studying the local diversity of rural livelihoods systems: An application of typological techniques for integrated rural development support in the Eastern Cape (South Africa). Working Paper 2005-05. Pretoria: Department of Agricultural Economics, Extension and Rural Development, University of Pretoria.

R Development Core Team (2007). R: A language and environment for statistical computing. $R$ Foundation for Statistical Computing, Vienna, Austria. Available at http://www.R-project.org.

Vandenberghe, J., \& Vanacker, V. (2008). Editorial: Towards a system approach in the study of river catchments. Geomorphology, 98, 173-175. https://doi.org/10.1016/j.geomorph.2007.01.025

Vanegas, R., Demoulin, F., \& Henry, S. (2012). Report on the field survey performed on Pichacay, Caldera 
and Llavircay study areas, Paute catchment, Ecuador. Technical report. Faculty of Agricultural Sciences (University of Cuenca, Ecuador) and Department of Geography (University of Namur, Belgium).

van der Ploeg, J. D. (2013). Peasants and the art of farming: A Chayanovian manifesto. (Agrarian Change and Peasant Studies Series; No. 2). Fernwood.

Available at https://edepot.wur.nl/424204

Weiss (2007). In J. D. van der Ploeg (2018). The new

peasantries. London, UK: Routledge,

https://doi.org/10.4324/9781315114712
Whatmore, S. (1994) Farm household strategies and styles of farming: Assessing the utility of farm typologies. In J. D. van der Ploeg \& A. Long (Eds.) Born from within: practice and perspectives of endogenous rural development, pp. 31-37. Assen, the Netherlands: Van Gorcum. 